\title{
Heightened consciousness and curriculum in a time of crisis
}

\author{
Naomi Kikue Poindexter ${ }^{1} \cdot$ Liesa Griffin Smith $^{2} \cdot$ Hongyu Wang ${ }^{3}[$
}

Accepted: 21 January 2021 / Published online: 15 February 2021

(C) UNESCO IBE 2021

\begin{abstract}
This article discusses heightened curriculum consciousness in a time of crisis due to Covid-19. A teacher, a principal, and a university professor in the United States offer intertwined perspectives on sharpened understandings that call for transforming our daily practice of education and everyday curriculum. The article includes four interrelated threads that underlie everyday curriculum but take on fresh meanings and urgent callings in a time of crisis: life and death, interdependence and collaboration, inequality and equity, and community beyond separation. Throughout discussions, storytelling and examples of how teachers and school leaders have responded to the difficult situation are also provided. Covid-19 is taken as a wake-up call to deepened understandings, heightened awareness, and relational interventions, so that the landscape of curriculum can be reimagined and recreated.
\end{abstract}

Keywords Curriculum $\cdot$ Covid-19 $\cdot$ Crisis $\cdot$ Inequality $\cdot$ Community

It is difficult to write about curricular responses to the Covid-19 pandemic when we are still in the midst of it. When we began to conceptualize and write this article in mid-April 2020, the United States was at its peak in the number of confirmed cases and deaths, with the worst outbreak in the world. Many schools were closed and teachers and students had adopted various forms of remote teaching and learning, living in a space of discomfort in

Hongyu Wang

hongyu.wang@okstate.edu

Naomi Kikue Poindexter

poindna@tulsaschools.org

Liesa Griffin Smith

1smith@tsas.org

1 Thomas Edison Preparatory School, 2906 E 41st St, Tulsa, OK 74105, USA

2 Tulsa School of Arts and Sciences, 1202 W Easton St, Tulsa, OK 74127, USA

3 Oklahoma State University-Tulsa, 700 N Greenwood Ave, Tulsa, OK 74106, USA 
which uncertainty, loss, and anxiety prevailed. We still do not have access to the bigger picture of the pandemic's impact. We would prefer a "delayed understanding" (Pitt 2003) to reach more insights, but, as educators, we also have to take the responsibility to respond despite the impossible situation, to understand what it means to live well together, and to educate and to be educated, all in a time of crisis.

Despite its danger, experiencing and making sense of this global pandemic can open up new possibilities. The crisis has heightened our consciousness of what we were already aware of but could not implement, what we have pushed away, and what has become invisible in our conventional schooling and education. Here, we focus not on something entirely new emerging from the pandemic and our responses to it, but on sharpened understandings that must transform our daily practice of education and everyday curriculum.

Curriculum here is understood as both content and process, "a complicated conversation" in which "academic knowledge, subjectivity, and society are inextricably linked" for intertwined individual and social reconstruction (Pinar 2004, p. 11). As a teacher, a principal, and a university professor in the United States, we will discuss four interrelated threads that underlie everyday curriculum but take on fresh meanings in a time of crisis: life and death, interdependence, inequality and inequity, and community.

\section{Death, grieving, and new pathways to life}

The Covid-19 pandemic inevitably forces us to directly confront suffering, dying, and loss in an intensified way, with heightened awareness of our own mortality. Teachers who are taking care of students in a time of crisis are also worried about their own safety, health, and well-being. This global pandemic frames an uncomfortable space of human uncertainty, pain, and vulnerability, within which we keenly feel the fragility of our humanity. Teachers find this awareness multiplied, as they attend to the intersections of their own needs, the needs of their families and loved ones, and the needs of their students.

Each teacher's concern for self is compounded by concern for students and others: the need to secure food and sanitation supplies, for example, and the need for financial resources in the midst of a collapsing economy. Teachers' teaching and parents' caretaking overlap now more than ever, with teachers and parents sharing the need to work from home, parent from home, teach from home, and navigate complex family dynamics while everyone shelters at home and lives through trauma. Students learn from home and experience a wide range of emotions, suffering as adults grapple with what is going on. These multi-layered experiences of collective loss and grief over loss, however, uncover and make visible the interconnectedness of humanity, an awareness often hidden in our individualistic daily living (Hershock 2012; Nagler 2004).

The issue of mortality is profoundly destabilizing. It is a human reality usually relegated to the periphery, but it is front-and-center in this crisis. It challenges educators to re-examine "the question of what is most worth our while in this limited life", a question all the more pressing during this time of crisis, recognizing that "it is after all, my life, the only life I will have" (Jardine 2012, p. 6). What is of most worth for school leaders, teachers, students? How do we hold and honor the tension of this mortal moment and transform it into a teachable moment? Holding these questions with respect and endeavoring to find our way to new possible answers will help us discover how we may come to live well together, work well together, and teach and learn well together. 
The consciousness of human vulnerability, mortality and loss, which is crystalized in a time of crisis, is actually part of life, and yet hardly an organic part of everyday education in the classroom. William Pinar (1992) contended that "the concepts and realities of death need to be integrated in everyday conversation, in everyday curriculum, not treated as exotic topics of extreme anxiety" (p. 99). We seldom discuss death with schoolchildren, with the good intention of protecting them from confronting pain and sorrow. But children already experience loss and death, and when they are able to grieve in the loving company of their teachers and classmates, they are less likely to be stuck in fear and more likely to make new meanings and embrace life in a fresh way. After all, "there is life amid death, life in death, life from death" (Pinar 1992, p. 94). Outside the official curriculum, teachers who connect curriculum with the lived experience of students take the initiative to bring such an important part of life into focus for students.

For example, Linda Laidlaw (1996) asked her kindergarten students to draw, write, and tell stories to remember their classmate who had recently died. A Japanese elementary teacher, Mr. Kanamori, in the documentary Children full of life (Kaetsu 2003), taught students to mourn loss and emerge from it in a life-affirming manner. Linda Skinner (Castle, Beasley, and Skinner 1996) worked with children to express their feelings towards the Oklahoma City bombing through the arts and activism, connecting students' activities with different academic subjects. These teachers all demonstrate the pedagogical wisdom of leading children to work through loss. In all these cases, tragedies happened and teachers took on an ethical responsibility to help their students grieve the loss through multiple means, rather than choosing not to make any pedagogical response. Moreover, these teachers had already built strong connections with their students, and they guided students, with care and compassion, to engage in difficult conversations when situations required this curricular commitment.

Loss can also be symbolic, rather than physical death. Children encounter such symbolic losses on a daily basis, especially in the Covid-19 pandemic: physical separation from family and friends, loss of the freedom to move around, or loss of the learning space. There is a delicate fragility in holding such conversations about loss, and it is important that opportunities be provided for children to grieve-but as invitations for engagement, not requirements to meet. In such a difficult space, students may have the chance to explore the profound significance, even sacredness, of human life in a multiplicity of lived experiences, social contexts, political landscapes, and interpersonal relationships, thus opening doors to other meaningful concerns that intersect their lives.

Living with death and human suffering through compassion and care is not a given, but a capacity that must be cultivated in the everyday curriculum and daily practice of education (Wang 2005). This capacity is also related to teachers' ability to work through their own loss. During this pandemic, educators are suffering from multiple layers of loss, not the least of which is the loss of their teaching self. For instance, teachers are required to learn new online platforms and systems and engage in meaningful dialogues with students, but many have little to no practice in online teaching. They are disoriented, much like their students without previous experience in online learning, who are confused.

With the familiar modes of teaching no longer adequate, teachers suffer reduced confidence in their own ability to teach. They express their feelings of regret and guilt, feelings of failure or insufficiency, as they attempt to teach from home in ways that no longer feel like teaching or serving their students, at least not like they could when they were in their classrooms. William Doll's approach to disturbance and chaos (Treuit 2012) is helpful in dealing with loss: "By their nature, open systems need challenges, perturbations, disruptions - these are the sine qua non of the transformative process" (as quoted in Wang 2016, 
p. 25). His conceptualization of perturbation and disequilibrium as necessary for transforming an open system helps us confront the pandemic in a different way.

How can teachers re-create their teaching identity by turning perturbation around for generative possibilities? Is it possible that a sense of losing their teaching self helps teachers understand their students better than before, since learners, by definition, must deal with confusion and uncertainty in their studies? No doubt, teachers' emotional work is necessary here for them to live with perturbation (Britzman 1998). Rather than pushing back against discomfort, accepting its difficulty makes it easier to learn other modes of relationships and ways of communication that can be educative. In some cases, technology facilitates connections: video chatting, texting, and emailing students opens new lines of communication and relational opportunities (Nowell 2014). Teachers have also found creative ways to offer psychological presence to students, and they have sharpened their sensitivity to students who need support. In a time of loss, confusion, and disequilibrium, we can discover new avenues for remaining open to the transformative possibilities swirling within and around us.

Educators' heightened awareness of mortality can open new pathways to life, but it depends on what kind of space is held open for teachers and students. Can it open up creative and life-sustaining potential, or shut it down due to newer forms of repression, control, and regimented accountability imposed by authorities? As school leaders and teachers are in the midst of this unfolding drama, the space leaders hold open for teachers and students should serve the immediacy of their living experiences, the now of all they are living and doing. It should also be a space in which we, as members of a school community, are able to recognize and honor our human frailty, and to honestly acknowledge our societal brokenness. Our everyday curriculum should explore important issues of life and death, not only individually but also collectively and cosmically, so that the individual body is connected to the communal body and the planetary body, rich in grace and benediction. Such a curriculum is open to life, to living, and holds great promise for the emergence of awareness, insights, and relationships.

\section{A heightened consciousness of interdependence}

The awareness of our vulnerability and our intersecting needs encourages us to consider new ways of being together that may have previously been hidden from our view. Nagler (2004) suggested that "one of the strongest needs of the human animal is for integration, for acceptance, community and fellowship" (p. 29). By confronting loss, death, and our limits as educators, we see more visibly this thread of interdependence and interconnection. Likewise, by refusing to project our negativity towards others, we find ways of handling this crisis productively.

In American culture, which privileges individual freedom and personal responsibility, interdependence is usually an invisible thread. A community is often perceived as the sum of individuals rather than being grounded in a sense of interconnectedness. However, during the pandemic, the coronavirus has touched the lives of many people from all walks of life, not only locally but globally. Its impact, although received differentially-which we will discuss next-makes the interconnection of life visible in an embodied, materialized, and shocking way. For instance, the virus does not respect the manmade boundaries of town, city, state or province, and country, but spreads wherever it will. We cannot rise above the most vulnerable populations, and our own health is at risk when others are struck down by the disease. What the pandemic exposes is precisely a "relationality that is neither 
exclusively of myself nor you, but is to be conceived as the tie by which those terms are differentiated and related" (Butler 2004, p. 22; italics original).

CNN anchor Brooke Baldwin (2020) shared what she learned as a coronavirus survivor-clarity and connection: "First, [I learned] that clarity comes from being quiet and listening to our feelings. And second, that connection is more vital to our health and happiness than we might care to admit". The dual priorities of going inward for clarity and going outward to claim connections should inform our everyday life and education. As air pollution reportedly decreased from the reduced human activity during the lockdowns, it is clear that there is an interconnection between humanity and the natural environment that we must acknowledge. Unfortunately, school curricula and academic studies are often structured in separate disciplines without organic connections. Interdisciplinary, transdisciplinary, embodied, storied, and experiential curriculum and teaching hold the promise of interweaving different forms of knowledge and highlighting the meaning of interdependence, through the shared lives of teachers and students. Any activities that are beneficial for connecting the body and the mind, the self and the other, and culture and nature can contribute to creating a curriculum of interdependence.

As Hans Sits and Rahat Naqvi (2015) pointed out, in curriculum "[w]e may overemphasize learning as primarily located in the individual" (p. 6). It is time to situate individual learning in relationality, in order to co-create a sustainable world. In the global context, shifting the primary focus away from the individual means challenging ethnocentrism and closed-minded versions of nationalism. The official curriculum of American exceptionalism is a good example to deconstruct (Loewen 1995). Pandemic-related vulnerabilities and suffering in the United States are similar to those of other nations, and the United States is definitely not doing better than others in containing and curbing the coronavirus. A sense of exceptionalism above all else tears apart the web of interconnectedness and easily projects shadows - in a Jungian sense (Jung 1953; Wang 2019)—onto others. The Trump administration is particularly good at scapegoating and refusing to take responsibility. American children should know the fuller version of the story.

While the dogma of "we are all in this together" has been echoed everywhere, conflict and antagonism are still abundant. The divisions and antagonisms between different levels of government and different groups of people play out on a daily basis. We need, at this current moment more than ever, local, national, and global cooperation, coordination, and solidarity for our shared struggles and recovery. Historical studies of earlier pandemics demonstrate that it is not only possible but necessary to rise above political and national divisions and foster collaborative efforts for public health (Spinney 2017; Summers 2012). Educators who are committed to the next generation and public education for a better world belong to this group: we must work from the bottom to transcend politics, in order to serve children better and shift relational dynamics away from competition and domination to cooperation and engagement.

\section{Storytelling: tensions, difficulties, and interconnections}

As Madeleine Grumet (1988) described, we "live in a world that divides culture from nature, domesticity from mystery, private from public" (p. 160). Yet, a pandemic upends these dichotomies, and we find ourselves living in a tentative and uneasy space where public and private collide: we stumble towards precious mysteries in our home-lives as the natural world intersects our society in unexpected ways. As we find our way, it is important 
to encourage teachers and students to tell their stories of this complex collision of lived experiences.

Stories illuminate the difficulty, creativity, failures, and breakthroughs (Fowler 2006) in our shared labors to teach and learn during a crisis. By holding open the space of possibility for something relational and transformational to emerge, through gentle attentiveness to these stories, we extend permission and grace for a multitude of complex thoughts and emotions (Smith 2021). Our deep need for recognition is stretched to the limit: we are vulnerable yet resilient, and sharing these stories is a demonstration of deep care. Honoring the intersections of these stories leads to acknowledging the interconnectedness and interdependency that exists in educational and curricular contexts, but which we may not have previously seen with such clarity. Storytelling takes on the "intergenerational task of opening, protecting, and cultivating the free spaces" (Jardine 2012, p. 4) in which teachers and students can explore difficulty together. This pandemic presses us as educators to reconsider and reimagine our educational and communal interconnectedness, which greatly depends upon the interwoven narratives of students, teachers, and school leaders.

As we cultivate a protected place for all members of the educational community to share their stories, the vulnerability and fragility made visible by the pandemic may be reframed to become generative, allowing collaboration to emerge, creativity to grow, and belonging to be nurtured. We may have fresh eyes with which to see one another and new ears with which to hear one another (Smith 2021). In this new understanding of one another, we may come to know a "kinship of compassion" (Chinnery 2007, p. 333) that transforms the nature of relationships and moves us further away from individualistic, competitive, and quantifiable modes of education.

The stories our teachers and students are telling now, the stories we honor and allow, and the stories we remember of this time give form to what is possible for our present moment, connecting it with the past and the future of education. For it is through these stories that we may come to be illuminated by "solidarity", which enables us to engage in "the often harrowing deeply dependent and interdependent work of confronting the mortality of the world that must be set right anew" (Jardine 2012, p. 4). Whatever dreams we have of education being "set right anew" (Arendt 1969, p. 192), these dreams will come into being out of the stories that we allow to emerge from this crisis.

\section{Teaching and learning online: Frustration and collaboration}

Teaching online or through other forms of distance learning is a difficult shift from the physical space of school. The necessity for social distance caused by the pandemic initiated a "punctuated" (Treuit 2012, p. 135) point for schools, where a new beginning happened rapidly and unexpectedly. This elicited a variety of individual responses from principals, teachers, parents, and students who had to deal with the trauma and transition quickly to a new platform. For teachers, a sudden change in the content delivery and technology of learning can create frustrating and even overwhelming conditions. Parents, many of whom are working from home, must now also homeschool their children. Within these destabilized adult worlds, students have to quickly learn online platforms not always used in everyday lessons, while they must also adapt to more independent learning in their daily routines. Many students falter or become stalled because distance learning is not adequate to meet their needs. At times, parents blame teachers and teachers blame the system, while students blame their parents, teachers, and the system. 
All members of the educational community can attest to the living reality of William Pinar's (2012) statement that "we are teaching [and learning] in a state of emergency" (p. 72). Though originally stated to contest accountability, standardization, and the negative treatment of teachers, it is so very applicable to today's crisis. In this emergency, the shared frustrations can also reveal our need for one another's compassion. When we realize that blaming others and issuing shadow projections do not work to relieve our burdens, and when we learn to hold tensions within the self and accept difficulty (Butler 2005), we look to one another for mutual learning and support, and unexpected forms of collaboration and working together emerge. For instance, younger teachers who are more familiar with online technologies begin to help some veteran teachers who need support. Students-digital natives-have begun offering advice on the use of technologies and encouraging their teachers to attempt new learning. Parents also begin to understand the difficulties inherent in teaching children.

Interestingly, in these scenarios the usual authority system-in which veteran teachers know more than young teachers and teachers know more than students - is disturbed, at least temporarily, to allow an unusual flow of communication and relationships. The usual tensions between parents and teachers can change when parents have a more appreciative understanding of the teachers' work. We can see that the thread of interdependence goes in all directions and challenges hierarchy and competition. We also see that in our everyday education, teachers learning from one another can become more reciprocal, and teachers also can learn from students. Teaching and learning with the help of communicative technologies in a time of difficulty reveals the possibility of a new space, where assistance and collegiality propel us into an improved sense of working together.

\section{Confronting inequality and shifting relational dynamics towards equity}

American society has an inequality problem that has been made more obvious through the spread of Covid-19 with its visible suffering and death. Vulnerable populations under the usual circumstances, such as the poor, the elderly, African Americans, Native Americans, and Latinx, were already subject to inadequate health conditions before the crisis, and they are now hit much harder. Most of their situations will become much worse in the aftermath of the pandemic, as they will suffer more from unemployment and social instability. The virus does not choose whom it targets, but the susceptibilities to infection and death, as well as the damages in its aftermath, are differentially and disproportionally distributed. Educational inequality is situated in such a social and cultural context.

\section{The gap of online access}

It is disturbing, outrageous, and painful to realize how much inequality exists in all areas of education. Bell hooks (2000) urged us to pay attention to the divisions and separations rather than espouse the comfortable position that there are no "evils of classism" (hooks 2000 , p. 5). Exposed against the backdrop of an indiscriminate virus are the conditions of social class within the microcosm of a school district or school. For example, in the school district where Naomi works as a teacher, students with computers and access to the Internet within their homes quickly transitioned into online learning and engaged with the content that was delivered. In contrast, children without home computers were asked to drive or 
walk to their school and borrow a Chromebook. Some children share a Chromebook with siblings and have access to the Internet for only one hour a day, when the Internet bus (a roving Wi-Fi hotspot) parks in their neighborhood.

Because some students also depend on schools for meals, the school district has designated certain buildings where parents can pick up food parcels as well as paper packets of grade-level curriculum. However, teachers will never see what these students complete because students who receive paper packets are not required to turn in their work, while those with electronic access can submit their work online immediately. Within this context, economically disadvantaged students are faced with almost insurmountable odds and are being pushed further behind. Equally concerning within this crisis are governmental moves to promote privatized systems, which on the surface seem like a possible solution to closing the access divide, but will do the opposite-increase the gap.

The issues of class are often hidden by race and gender (hooks 2000), but during this time, class is clearly visible because students without access to technology or a working phone can simply disappear from their classes. The educational system's rapid response to the pandemic was not pre-planned, but its inadequacy makes many educators realize how a crisis can magnify the effect of the access gap on students' learning and well-being. Students from lower social classes are often preoccupied with survival rather than with learning through a new, inaccessible electronic platform. Ironically, for some students, the school they attend is the safest place they can go to escape from poverty or domestic violence. So, with the closing of schools, they have nowhere to turn. No wonder that teachers lose some students in online teaching or remote learning.

Education is a human vocation that centers around people. Aoki (2005) posited that education is never neutral and encouraged educators to critically reflect on the situational praxis in which teachers and students engage curriculum. Looking at the implementation of education during this crisis, we see the huge separations much more clearly, and as Aoki suggests we need to engage in critical reflection, to clarify the orientations, assumptions, and intentions upon which curriculum, thought, and action rest. What can we, as educators who strive for a more equitable educational experience for all students, do to clarify "where we stand" (hooks 2000, p. 9) and help students from all backgrounds connect with the curriculum?

\section{Equity, difference, and global diversity}

The pandemic has laid bare the many nuanced layers of long-standing societal inequities. As states, cities, school districts, and individual schools struggle to provide ongoing education for students, profound social, political, and economic challenges bring complex difficulties for the meaningful continuation of teaching and learning. As schools scramble to provide resources to families and students, deeper and intersecting issues of inequity surface, issues which go beyond the concerns with access and which require productive relational dynamics. Teachers fear for their most vulnerable students, knowing that their absence from the school building reduces their learning opportunities and diminishes essential nurturing relationships, and that even if these students have online access, their suffering will not be reduced. Students lament the purposelessness of doing homework in a world turned upside down. In such a context, top-down standardization and accountability, not to mention an educational system framed upon assessment, appear more meaningless than ever, as these reforms have already been sharply criticized as pushing away diversity and making equity impossible (Taubman 2009; Pinar 2004). 
Hershock (2012) adopted a lens of nondualistic interdependence to privilege the notion of equity over the notion of equality, forming an orientation for redirecting relational dynamics towards a mutual flourishing in the human-with-the planet relationships. For him, equality suggests quantifiable sameness that reinforces the modern Western notion of separate individualism; it is based upon commonality but neglects the role of diversity. By contrast, equity that is based upon relational ontology is "a qualitative function of reconfiguring axiological resonances within and among ecological, economic, and ethical domains" (p. 236; italics original). He argued that the value of the market and technology should be secondary to the value of "greater diversity - the relationally concrete enhancement of mutual contribution to sustainably shared welfare" (p. 223). Realizing greater equity requires relational intervention that gives meaning to relational patterns that are nonlinear, complex, and inclusive.

Curriculum can provide such an intervention, pursuing greater equity by transforming both the content and the process. Teachers have already incorporated topics related to Covid-19 in their teaching of different subjects. An interdisciplinary approach that draws upon students' own experiences holds great potential for highlighting how interdependent and yet different we all are, as well as what we can do to change our relationships in order to co-create an equitable, shared space that cares for all (including non-human beings). It is a curricular labor in which "self-knowledge and collective witnessing are complementary projects of self-mobilization for social reconstruction" (Pinar 2004, p. 37). Relational dynamics start with working from within to acknowledge and integrate internal diversity and extend outside to build equitable relationships across societal and ecological diversity (Wang 2019). We must transform curriculum and its relationships so that students' internal landscape connects with the external landscape, through academic studies to cultivate their capacity for equitable differentiation and distributions.

In the global context, after the September 11th attacks on the US and the US war against Iraq, Judith Butler (2004) asked thought-provoking questions to confront global violence: "Who counts as human? Whose lives count as lives? And, finally, what makes for a grievable life?" (p. 20; italics original). With the differentiated norms of recognition that protect certain lives and make mourning possible while neglecting other lives and rendering them ungrievable, she called for "insight into the radically inequitable ways that corporeal vulnerability is distributed globally" (p. 30). Although not the same, the Covid-19 disaster highlights inequality and inequity issues both within the United States and around the world, as the physical and social bodies of vulnerability are disproportionally distributed.

As we revised this article for publication in mid-October 2020, Black Lives Matter protests swept through the United States. While it is beyond the scope of this article to discuss these protests fully, since their origin came before the Covid-19 pandemic, they stand out as a striking example of the inequitable distribution of corporeal vulnerability, as the pandemic illuminates the deadly consequences of racism. Covid-19 teaches us that humanity cannot rise above the most vulnerable population in the society and that if we cannot grieve for the other's loss, we cannot grieve our own loss. Racial inequity and Black bodies' subjection to police brutality and systemic discrimination are also related to the global effects of Western colonialism. This also reminds us that the indigenous people also suffered from the genocidal disease spreading in their initial encounters with colonists in the United States. Questioning whose lives count as fully human and grievable is still a critical issue to confront today.

The political and social reality of producing ungrievable individuals and collective bodies is closely intertwined with the sweeping impact of the global market in the contemporary era. Hershock (2012) pointed out, "The distribution of risks, threats, and hazards... 
further disadvantage[s] those already most vulnerable to the global effects" (p. 215). In the Trump administration's response, clearly the concerns with the market (and related election politics) have been prioritized over public health, as apparently some people's bodies are disposable in order to protect and sustain the market. The critical questions of how to increase equity through building up relational strength requires decentering global capitalism and allowing diversity to play a positive role in enhancing organic relationality. America's myth of a classless society and the lack of global concerns in American curriculum have to be changed, in order for us to deal with equity issues in both local and global contexts.

\section{Creating a community that hosts both separation and connection}

Personal and interpersonal presence is valued in curriculum as community building for educators (Smith 2021; Wang 2016). But during the pandemic, such a sense of community has been radically changed, with physical presence near each other being replaced by other forms of presence, mostly through the aid of technology such as cell phones and virtual meetings. The coronavirus has placed us outside of our comfort zones and isolated us from the usual patterns of relating to others. With communal classroom engagements disrupted and the lived experiences of teachers and teaching destabilized, we question what it means to be a teacher. Teachers' identities are deeply relational, and we become strangers to ourselves as we now live in a strange world in which students can also become strangers. While students stay home, many teachers are required to teach in the classroom through virtual platforms. The mostly empty school building, with teachers alone behind their computers, is strange. The instructional reliance on technology without in-person interactions is strange. It is strange that the teacher can only see students' names on black screens, as some schools allow students not to turn on their microphones or screens during the virtual lesson. The teaching profession relies on the relationship between the teacher and students, but now teachers are teaching literally faceless students: how do these students even know that their teacher cares about them?

Maxine Greene (1973) discussed the existential position of teachers as strangers to challenge the established and open up new possibilities: wide-awake, critically aware, questioning, and engaging. Alan Block (1998) complicated this notion from the view of a Jewish teacher, as a stranger "not by choice but by historical necessity" (p. 20), and pointed out that it is a site that the teacher must intentionally re-orient to achieve its generative potential. During the Covid-19 pandemic, teachers are thrown into the site of being strangers to themselves, not by their willingness but by unexpected circumstances. Though not by choice, questioning and engaging in different ways must be intentionally pursued through shifting lenses. Can the radically shifting and uncomfortable space that educators are experiencing nurture new visions of community that are not so easily seen in everyday patterns of relationships? What does it mean to build a community when educators' usual means of communicating with their students are disrupted? Can a sense of belonging that transcends our physical separateness still be possible? If teachers become strangers to themselves, what can they do to navigate a complex, confusing, chaotic realm while also helping their students navigate such a realm?

Social distancing is meant to keep us safe, but it removes teachers and students from each other's physical presence. Online platforms help teachers keep interacting with students but add filters to pedagogical engagements. The flexibility of time, space, and place may make teaching and learning available in the asynchronous world of digital learning, 
but it can also make us feel like exiles cast away from the communal learning experience of the classroom. With all that is gained in continuing to provide education through video conferences, media platforms, and digital classrooms, there is human loss, relational diminishment, and psychological complexity. Because the social distancing came at the end of the academic year, most teachers had already had three-quarters of a year with their students to build a sense of community, without which online teaching would be even more difficult. These paradoxical experiences may help us recognize more clearly the relational and communal elements of teaching and learning that enrich us (Wang 2016; Miller 2005; Noddings 1984), and to cultivate and renew them more energetically when we are able to return to classrooms in the future.

In discussing community building during the pandemic, we cannot avoid the impact of community spread of the virus. Naomi lived through intense fear, anxiety, and sadness when the husband of a teacher in her school died, the first death in her city due to Covid19. Sadly, he died alone. Imagine the struggles that teacher and her family endured in isolation, forced to self-quarantine, dealing with the shock of their loved one's death. Concurrent with this profound personal loss, the teacher kept teaching through distance learning and was present for her students while she parented her own grieving children. At the same time, many people within that large school must have retraced their steps to the last time they were in close contact with that teacher, and then counted forward to determine the day on which they could say they were not infected. The students and their parents were concerned as well, despite district communications in an attempt to calm the school community. Stories of grief, fear, and courage in such a strange time for any community are deeply intermingled and have a profound impact on the emergent shape of a community. Can a compassionate community (Guberman 1996) be built given the pervasive fear of community spread of the virus?

While heartbreaking stories abound, teachers, parents, and students attempt to find courage and strength to continue teaching and learning, while holding complicated feelings about their educational experiences. Despite the difficulty, many schools and teachers are dedicated to creating new ways of building a caring community (Noddings 1984) in which mutual support, care, and collaboration in different forms are becoming the new norm. School personnel, parents, and students seek creative ways to celebrate milestones like graduating from high school. Teachers improvise, using video messages of encouragement to recognize their students' progress and effort. In some cases, district curricular and grading guidance are open to the interpretation of each teacher, so teachers have more flexibility than before. Teachers are living with their strange selves in a weird time, and we are rallying to educate. We have not abandoned our moral obligations to students and responsibility to teach, and our steadfastness must be part of the curriculum story of community building.

As governments and schools struggle to navigate the system of measurement, performability, and standards, students, teachers, and school leaders are overwhelmed by fears of failure and frustrations when the usual assessments do not align with the daily realities of living and surviving during a pandemic (or with everyday experience in general). The school community is at risk of fracturing under external pressures. Some educational authorities respond by issuing waivers and suspensions of accountability protocols and normal regulations of assessment, while disciplinary arrangements of schools become much looser, which temporarily creates a space where teachers and students can focus on educational experiences. The fact that the cohesion of a school community benefits from the removal of external regulations demonstrates that a compassionate community can be sustained and cultivated without standardized mandates. 
With crisis, there is also opportunity. Our shared strangeness, disorientation, and destabilization as school leaders, teachers, students, and parents can suggest divisions, fracturing, and distortions-but equally so, this educational moment may also suggest possibilities for new experiences and expressions of community (Fowler 2006). It may be possible to resist fragmentation, and instead shift the relational dynamics toward building a community that welcomes the stranger. Butler (2004) pondered: "My own foreignness to myself is, paradoxically, the source of my ethical connection with others. I am not fully known to myself, because part of what I am is the enigmatic traces of others" (p. 46). Julia Kristeva suggested that suffering, vulnerability, and weakness can become the bridge for the self to be connected with the (strange) other. In such a community, "[w]e recognize others, as foreigners, as strangers" (Guberman 1996, p. 100). Only by recognizing that the self can be vulnerable and host the unknown other within can one expand the space for connecting with others at a distance. Thus, we might utilize the time and space offered by the crisis in such a way that members of the school community become more aware of the interconnectedness of our lived experiences, our part in shaping the common good, and our intertwined futures.

Community is not simply the addition of separate individuals or social groups but is embedded in a particular quality and direction of relational dynamics that emerge in the process. According to Hershock (2012), diversity within a community enriches the complexity and mutuality of its relationships. Maxine Greene also suggested that "our diversity should be celebrated and recognized as the essence of our cultural cohesiveness" (Goodman and Teel 1998, p. 63). Interestingly, the language of "war" is also invoked and used in dealing with the pandemic, both nationally and globally, and yet nothing can be more divisive than a brutal war. It is true that news can be filled with talk about trade wars, cultural wars, the war on drugs, the war on poverty, and the war on terrorism. Hillman (2004) suggested that war has become normalized in our everyday life. However, is not the effort to eliminate the danger of dying on a massive scale across the globe actually the exact opposite of war's desire to eliminate the human enemy, who must die on a massive scale for winning battles?

When the unity of a community depends on invoking a common enemy, the mentality of "us versus them" through dualistic divisions only leads to more fragmentation, exclusion, and the militant, hyper-masculine posture (Burns 2018; Pinar 2004) which has led us to today's difficulty in the first place. Dualist thinking is common in everyday curriculum and still lingers in a time of crisis. Resisting the narrative of fragmentation and division, we might learn to recognize "unity in what we see as separate" (Grumet 1988, p. 191) and experiment with new forms of engagement that acknowledge the potential for "relational change and creativity" (Hershock 2012, p. 28). In this way we might experiment with holding teaching and learning within a gracious space, working to cultivate new curriculum practices that differ from the individualistic and competitive race with achievers and failures. We need to pursue instead a humane endeavor, which is an aspiration of the human spirit to grow and change and become, an embodied, relational, interdependent and mutually sustaining educational project of adults and children sharing life and creating the world anew.

If we acknowledge the potential for "coming together in [our] pluralities and [our] differences" (Quinn 2014, p. 219), we may be able to cultivate a sense of belonging that transcends our physical separateness, our experiential complexities, and our relational differences. Such a new form of relationality suggests hopeful curriculum possibilities for building future generative communities (Smith 2021). In drawing together the complex and intersecting living experiences of school leaders, teachers, students, and their families, we 
may find new forms of commitment and relationships that may aid us in our future work to build "communities and collaborations without hierarchies but also without mandated consensus" (Miller 2005, p. 82). These new opportunities suggest that we may open ourselves to the unexpected, the different, and the uncomfortable, and in so doing cultivate new patterns of relationships and community (Greene 1995).

As we live in this moment of difficulty, the future is embedded in the present. How we experience and respond to the crisis will contribute to how we create the future. Is it possible that the crisis will help us initiate fundamental changes and create new forms of life? Will we stay more or less the same after the pandemic passes? Or will more mechanisms of domination and hierarchy be enacted, which cannot keep us from slipping down the destructive slope? How the uncertain tomorrow unfolds depends on what we do today. We must take Covid-19 as a wake-up call to awakenings and relational interventions, so that the landscape of curriculum can be reimagined, reconstructed, and recreated. Let us cultivate courage, compassion, and capacity for attending to our heightened consciousness, sensing new openings to life, and following curricular pathways towards connectedness, clarity, equity, community, and creativity.

\section{References}

Aoki, T. T. (2005). Curriculum implementation as instrumental action and as situational praxis. In W. F. Pinar \& R. L. Irwin (Eds.), Curriculum in a new key: The collected works of Ted T. Aoki (pp. 89-110). Mahwah, NJ: Lawrence Erlbaum.

Arendt, H. (1969). Between past and future. New York, NY: Penguin Books.

Baldwin, B. (2020). How fighting coronavirus taught me about the gift of connection. CNN. https://www. cnn.com/2020/04/19/health/coronavirus-diary-sickness-brooke-baldwin/index.html.

Block, A. A. (1998). 'And he pretended to be a stranger to them...': Maxine Greene and teacher as stranger. In W. F. Pinar (Ed.), The passionate mind of Maxine Greene: 'I am...not yet' (pp. 14-30). London: Falmer Press.

Britzman, D. P. (1998). Lost subjects, contested objects. Albany, NY: State University of New York Press.

Burns, J. (2018). Power, curriculum, and embodiment. London: Palgrave Macmillan.

Butler, J. (2004). Precarious life: The powers of mourning and violence. London: Verso.

Butler, J. (2005). Giving an account of oneself. New York, NY: Fordham University Press.

Castle, K., Beasley, L., \& Skinner, L. (1996). Children of the heartland. Childhood Education, 72(4), $226-231$.

Chinnery, A. (2007). On compassion and community without identity: Implications for moral education. In D. Vokey (Ed.), Philosophy of education 2006 (pp. 330-338). Urbana-Champaign, IL: Philosophy of Education Society.

Fowler, L. C. (2006). A curriculum of difficulty: Narrative research in education and the practice of teaching. New York, NY: Peter Lang.

Goodman, J., \& Teel, J. (1998). The passion of the possible: Maxine Greene, democratic community and education. In W. F. Pinar (Ed.), The passionate mind of Maxine Greene (pp. 60-75). London: Falmer Press.

Greene, M. (1973). Teacher as stranger. Belmont, CA: Wadsworth.

Greene, M. (1995). Releasing the imagination. San Francisco, CA: Jossey-Bass.

Grumet, M. (1988). Bitter milk: Women and teaching. Amherst, MA: The University of Massachusetts Press.

Guberman, R. (Ed.) (1996). Julia Kristeva: Interviews. New York, NY: Columbia University Press.

Hershock, P. (2012). Valuing diversity: Buddhist reflections or realizing a more global equitable future. Albany, NY: State University of New York.

Hillman, J. (2004). A terrible love of war. New York, NY: The Penguin Press.

hooks, b. (2000). Where we stand: Class matters. New York, NY: Rutledge.

Jardine, D. (2012). Pedagogy left in peace: Cultivating free spaces in teaching. New York, NY: Continuum Books. 
Jung, C. G. (1953). Two essays on analytical psychology (R. F. C. Hull, Trans.). Princeton, NJ: Princeton University Press.

Kaetsu, N. (2003). Children full of life [Video]. NHK TV. https://www.youtube.com/watch?v=M9u1w FlU0Ms.

Laidlaw, L. (1996). Dangerous writing: Life, death, and curriculum. Journal of Curriculum Theorizing, 12(4), 44-46.

Loewen, J. W. (1995). Lies my teacher told me: Everything your American history textbook got wrong. New York, NY: Touchstone.

Miller, J. (2005). Sounds of silence breaking: Women, autobiography, curriculum. New York, NY: Peter Lang.

Nagler, M. (2004). The search for a nonviolent future: A promise of peace for ourselves, our families, and our world. Maui: Inner Ocean.

Noddings, N. (1984). Caring: A feminine approach to ethics and moral education. Berkeley, CA: University of California Press.

Nowell, S. D. (2014). Using disruptive technologies to make digital connections: Stories of media use and digital literacy in secondary classrooms. Educational Media International, 51(2), 109-123.

Pinar, W. F. (1992). Cries and whispers. In W. F. Pinar \& W. M. Reynolds (Eds.), Understanding curriculum as phenomenological and deconstructed text (pp. 92-101). New York, NY: Teachers College Press.

Pinar, W. F. (2004). What is curriculum theory? New York, NY: Routledge.

Pinar, W. F. (2012). What is curriculum theory? (2nd ed.). New York, NY: Routledge.

Pitt, A. (2003). The play of the personal: Psychoanalytic narratives of feminist education. New York, NY: Peter Lang.

Quinn, M. (2014). Peace and pedagogy. New York, NY: Peter Lang.

Sits, H., \& Naqvi, R. (2015). Framing peace: Think about and enacting curriculum as "radical hope". New York, NY: Peter Lang.

Smith, L. (2021). Curriculum as community building: The poetics of difference, emergence and relationality. New York, NY: Peter Lang.

Spinney, L. (2017). Pale rider: The Spanish flu of 1918 and how it changed the world. New York, NY: Public Affairs.

Summers, W. C. (2012). The great Manchurian plague of 1910-1911: The geopolitics of an epidemic disease. New Haven, CT: Yale University Press.

Taubman, P. M. (2009). Teaching by numbers: Deconstructing the discourse of standards and accountability in education. New York, NY: Routledge.

Treuit, D. (2012). Pragmatism, post-modernism, and complexity theory: The "fascinating imaginative realm" of William E. Doll, Jr. New York, NY: Routledge.

Wang, H. (2005). "Falling leaves", wound, and curriculum meanings. Journal of Curriculum and Pedagogy, 2(2), 139-156.

Wang, H. (2016). From the parade child to the king of chaos: The complex journey of William Doll, teacher educator. New York, NY: Peter Lang.

Wang, H. (2019). An integrative psychic life, nonviolent relations, and curriculum dynamics in teacher education. Studies in Philosophy and Education, 38, 377-395.

Publisher's Note Springer Nature remains neutral with regard to jurisdictional claims in published maps and institutional affiliations.

Naomi Kikue Poindexter was born and raised in Pearl City, Hawaii. Poindexter began her career as a learning disabilities instructor and later taught secondary English. In 2008 she earned a national board certification (English/Early Adolescence). She was in teacher leadership for much of her 36 years in public education: serving two years on a state committee to oversee teacher education programs; and then at the district and school levels, as a school team leader, department chairperson, and in the school exchange program. Recently, she was a district coach for new teachers and has earned a PhD from Oklahoma State University.

Liesa Griffin Smith had a nomadic childhood, living in both the United States and Israel. She settled in Oklahoma, where she later began her career in education as an English and Art teacher, working in many diverse educational contexts, including: public schools, private schools, homeschool co-ops, public charter schools, and continuing adult education programs. For the last eleven years, Smith has served as the Lead High School Principal at a public charter school in Tulsa, Oklahoma. She is also an adjunct instructor, 
teaching graduate courses in curriculum at a regional university in the education leadership program. Smith earned her PhD in Curriculum Studies from Oklahoma State University.

Hongyu Wang is a professor in curriculum studies at Oklahoma State University-Tulsa. Her research and teaching areas include nonviolence education, curriculum theory, international curriculum dialogues, psychoanalysis and education, and college curriculum and teaching. She has authored books and articles in both English and Chinese, including From the Parade Child to the King of Chaos: A Complex Journey of William Doll, Teacher Educator (Peter Lang, 2016), Nonviolence and Education (Routledge, 2014), Cross-Cultural Studies in Curriculum: Eastern Thought, Educational Insights (co-edited with Claudia Eppert; AESA Critics' Choice Award and AERA Outstanding Book Recognition) (Lawrence Erlbaum, 2008), and The Call from the Stranger on a Journey Home: Curriculum in a Third Space (Peter Lang, 2004). She is currently finishing a book titled Contemporary Daoism, Organic Relationality, and Curriculum of Integrative Creativity. 